\title{
Institutional Support in Managerial Capacity Building and SMEs Growth
}

\author{
Solomon Kwarteng Forkuoh*, Yao Li, Mavis Boatemaa Ampadu, Michael Aboagye Osei \\ School of Management and Economics, University of Electronic Science and Technology of China (UESTC), \\ Chengdu, China \\ Email: "Forkuoh6@hotmail.com
}

Received 18 December 2015; accepted 3 April 2016; published 6 April 2016

Copyright $@ 2016$ by authors and Scientific Research Publishing Inc.

This work is licensed under the Creative Commons Attribution International License (CC BY).

http://creativecommons.org/licenses/by/4.0/

(c) (i) Open Access

\begin{abstract}
Quality managerial skills have been cited as very crucial and important ingredient in the success of enterprise and it is ranked high among other success factors of enterprises in Ireland. As many of the traditional sources of competitive advantage (technology, economies of scale, patents etc.) diminishes in value, the role of a skilled motivated and flexible workforce has become more prominent. In contrast, most SMEs do not have access to quality labor force, which normally translates to 1 productivity and uncompetitive, and in the long run affects the national growth and development. It is therefore not an act of accident to see several government and other institutions support SMEs train and maintain quality workforce. The task before this researcher is to assess the impact of institutional support in the provision of managerial capacity building on the growth of selected SMEs in Ghana. Using firm level data from 500 SMEs from the ten regional capitals of Ghana, the results indicated that the provision of institutional support in the training of procurement personnel, bookkeeping and accounting and business plan preparation experts had positive impact on the growth and development of the SMEs.
\end{abstract}

\section{Keywords}

Managerial Capacity Building, SMEs Growth, Institutional Support, SMEs Challenges

\section{Introduction}

Several challenges including inadequate access to finance, skilled labor and limited market size faced by SME restrict their growth and development in both developed and developing nations [1]-[4]. Research conducted on the challenges of SMEs by [5]-[7] also asserted that, numerous challenges SMEs faces in their operations are translated into slower growth, whiles the research went further to show that SMEs in countries with well-devel-

*Corresponding author.

How to cite this paper: Forkuoh, S.K., Li, Y., Ampadu, M.B. and Osei, M.A. (2016) Institutional Support in Managerial Capacity Building and SMEs Growth. Open Journal of Business and Management, 4, 188-205. 
oped financial and legal systems are less affected in the quest for growth. Further research also shows that 50\% of SMEs in developing countries are not able to go beyond five years of their operations and this has been partly attributed to challenges SMEs face [8]-[10].

Behind the success story of SMEs in China, still lies a chuck of peculiar challenges that hinders them from reaching the maximum potentials [11], as there was a drop in Chinese export from $20 \%$ to $80 \%$ with over 900 toy export companies closing down in 2008, and this has been attributed to a number of challenges faced by the Chinese SMEs [12], as SMEs challenges in most cases rises from the difficulties of absorbing the large fixed cost in both the short and long run of their operations, which normally lead to absence of economies of scale [13]-[15]. Based on the degree of their impact on the growth of SMEs, challenges are grouped under the following; financial, marketing, institutional policies and managerial issues [16]-[22].

Quality managerial skills have been cited as very crucial and important ingredient in the success of enterprise and it is ranked high among other success factors of enterprises in Ireland. As many of the traditional sources of competitive advantage (technology, economies of scale, patents etc.) diminishes in value, the role of a skilled motivated and flexible workforce has become more prominent [23]. As [24] put it, "the survival of every enterprise is dependent on the effective management of human resources" as there is a positive correlation between employment promotion and enterprise efficiency. [24] and [25] in quoting from an old military proverb said “there aren't any bad soldiers, there are only bad officers", thereby placing much emphasis on the capabilities on manager as changers and makers of organizations. [26] reiterated the benefits a firm derive from making of individual skilled employees and committed to achieving common objectives within the firm, while at the same time the firm supported and encouraged to achieve stated objectives. [27] also established that if a firm's human capital management and employees were strong enough to give a competitive advantage over other firms and also strategically helped in achieving the goals of the firm, then such human capital was a strategic asset of the firm. From the behavioral perspective, [28] suggests that an effective HR management system will acquire, develop and motivate the behaviors necessary to enhance firm performance [23] [28].

Yet, poor managerial skills in SMEs are recognized as an acute problem worldwide, the OECD working group on SMEs has identified managerial weakness as a key factor in the failure of small businesses and is more prominent in developing countries and also smaller firms [28] [29].

Managerial incompetences are more prevalent in SMEs as compared to the larger companies because SMEs (entrepreneurs) do not have the managerial capabilities and are also not prepared to hand over the management of the business to the professional managers for some reasons such as lack of trust, risk among others [30]. In some cases, some SMEs are too "closed" and inward looking thereby preventing non-core employees or nonfamily members (in the case of family business) to be involve in decision making, this block "outside" influence which may be positive for the growth of the business.

Depending on the activity area, the staff and business owner may not have the requisite qualification and experience to run the day to day activity of the firm to achieve the needed target. As it has been established that SMEs are bedeviled with problems of recruiting and retaining high caliber managerial staff as compared with their larger business counterparts. Research conducted by [29] in six countries: Canada, Finland, Germany, Japan, United Kingdom and United States of America established that, high quality personnel adapt quickly in the fast evolving market and intense competition. One of the finding was that, formal management training reduce the failure rates of small firms.

These findings were in line with the outcomes of earlier researches by [31] in the USA, that good management practices is associated with high performance and growth of businesses in the form of sales and profits. Whiles [32] also attributes the high rate of business failure to weak and inexperience management team of businesses in Canada.

Research by [33] on the growth of SMEs in the UK also supported the assertion that, SMEs achieved growth through the adaptation of prudent managerial and organizational structure dynamic enough in meeting the ever changing demands in the sector. In the quest to find out why SMEs lag behind the larger firms in terms of provision of external managerial training [29], it was clear that, SMEs lack the requisite manpower.

\section{Literature Review}

\subsection{Empirical Evidence on Institutional Support and SMEs Growth}

Several researcher findings shows that there is a positive correlation between institutional support and SMEs [34] 
[35]. As there is ample empirical evidence on the positive impact of external institutional support on SMEs growth in the UK, since the recommendations by Bolton Commission. In a comprehensive survey by [35], on the impact of the external support on over 5000 SMEs in the UK, the results indicated that, 19\% of the SMEs had increased their workforce (number of employees gone up), 64\% were employing the same number, while 17\% have reduced the workforce, but in the end there was a net employee increase over the survey period from 2012 to 2013. Also $72 \%$ of the SMEs had an increase in their annual profit over the period under review [35]. Out of the 532 SMEs surveyed, 45\% had sought for external business support. This finding was in line with the earlier study by [34], where there was a positive correlation between the external institutional support and SMEs growth in the UK.

In determining the impact of external institutional support on the operations of SMEs in the area of access to external finance, growth, decision marking, managerial training and capacity building, in all there was a positive impact on the growth and development of the SMEs [36]-[39]. Similarly, research by [36] [39] [40], shows the vital role play by external accountants in the SMEs sector, which confirms the rationale for an increase in demand for external accountants by SMEs in the area of external support.

Studies conducted by numerous researcher [41]-[43] on the impact of institutional support on SMEs growth in the US and most parts of Europe, also indicated a positive correlation between the support and SMEs growth.

A renewed Ghana government policies on SMEs growth were intensified upon the introduction of the second Growth and Policy Reduction Strategy (GPRS II 2006 to 2009), and Growth Agenda (GA III 2010-2013), which saw the state increasing it support to SMEs in diverse forms. All with the aim of reducing poverty and moving Ghana to the middle-income country, with SMEs growth as the catalyst. The positive impact of the policy on the economy of Ghana led the World Bank and [44] ranking Ghana $10^{\text {th }}$ in the best Global reformer for the period 2006 to 2009.

Specifically, obtaining external advice in the field of business strategy and staff recruitment have a positive impact on the growth of SMEs, these findings came out from a research conducted by [43] on the impact of institutional support and SMEs growth in member countries.

It is therefore not surprise for an upsurge in demand for external institutional support in the form of Accountants' advice financial and managerial support from several support institutions over the years. [45] said this shows that there is a growing trust and interest in the activities of the support institutions globally [46].

\subsection{Training in Book Keeping and Accounting and SMEs Growth}

Research has shown that sixty percent (60\%) of SMEs fail within few years of their operation [47], this has been partly attributed to poor or lack of proper recordkeeping especially among the small enterprises, this is line with the earlier findings of [48] where poor finance management has been posted as the main cause of failure on the MSEs.

Again, proper bookkeeping has been acknowledged by as one of the major ingredients for business [49] survival and growth, since it reduces the risk of hitting cash flow crunches. A strong relationship between business performance and the level of training in the business management especially in business finance record keeping has also been established by [47], on the premise that, Knowledge and skills in bookkeeping is especially one major factor that impacts positively on sustainability and growth of SMEs.

Proponents for the practice of proper bookkeeping practices based their stance on Decision Theory on Accounting which was pioneered by Herber Simon in 1952, which is concerned with identification of the best decisions to use decisions making. This has been confirmed in a research by [50], that proper book keeping positively enhanced SMEs growth as measured by profitability and increased business expansion.

Despite the significant role bookkeeping and accounting plays in the survival and growth of businesses, most SMEs do not practice it, as research by [51] indicated that almost 50\% of SMEs surveyed practice simple booking with rest not keeping any financial records. The story is worse among SMEs in developing countries, where less than $30 \%$ of SMEs surveyed in sub Saharan African countries were practicing simple booking with around $70 \%$ not keeping records at all [49].

Lack of keeping accurate records was highly blamed on the lack of skilled labor in this field by the owners or managers. The study further revealed that the owners and managers of MSEs were highly willing to learn more about how to keep accurate records of their business transactions, but due to the prevailing unfavorable conditions, such as high cost and technicalities involve always act as impediments to its adoption [52]. Looking at the negative effect the absence of proper bookkeeping and accounting practices have on the performance of most 
SMEs in the developing countries, there has been a call for governments and other institutions to support SMEs in the field of bookkeeping in the form of training, workshops, and provision of subsidized accounting services to those SMEs [53]-[55].

Based on the literatures and empirical evidence reviewed, we hypothesized that, H1: provision of institutional support in the area of bookkeeping and accounting will have positive impact on the growth and performance of SMEs.

\subsection{Management Training in Business Plan Preparation and Implementation and SMEs Growth}

There are ample empirical evidence on the positive correlation between business plan preparation and the growth of businesses [56] [57], even though there has been equally negative contribution of business preparation on the growth of SMEs [58], but as Team [59], put it "Companies that plan do better than companies that don't, but they never follow their plans.”-Ansoff's Law. These findings have been reechoed by [60] that, SMEs that practice business planning, financially outperformed their non-planning peers, whiles [61] found that successful small high tech companies relied on strategic planning to assure their long-term development and growth. [62], was of the view that, business planning help reduces the risk in doing business, since it reduces uncertainties, thereby reducing business failures. In supporting the positive impact of business planning on the SMEs growth, [63] and [60] associated fast growth with firms that uses business plan.

Several reasons for the positive contributions of business planning to the growth of SMEs includes the fact that planning improves organizational decision making by helping managers to find gaps and missing information and make optimal rational decisions, by systematically examining manager's assumptions and evaluating "thought experiments" before resources are committed to implement change [64], planning stimulates generation, collection and analysis of crucial information regarding external and internal environments, expanding the number of feasible options that receive attention and evaluation [65], and finally, planning facilitates the process of attaining organizational goals, in a systematic way, with concrete action steps [66].

Now the issue is, if preparing business plan will grant the numerous advantages, then why most SMEs refuse to prepare it? The cost involves in the preparation, technicalities and ignorance of its importance to entrepreneurs are among several factors that hinder the preparation.

This calls for external support from government and other institutions to assist SMEs in the preparation and implementation of business plan. We therefore hypothesized that, H2: the provision of institutional support to SMEs in the preparation and implementation of business plan will have positive impact on the growth and development of the SMEs.

\subsection{Managerial Training in Procurement Procedures and SMEs Growth}

The size of SMEs together with limited resources and shortage in resources personnel have been cited as a major hindrance to sourcing government and other big contract, for in most instances they are outplayed by their larger counterparts. In view of the imbalances, some governments in the developed countries protect their SMEs in the bidding and procurement process through bid price preferences that load the lowest non-SME bid or provide a discount to the lowest SME bid and set asides which provide quotas for SMEs. Policy in this area seeks to tackle the disadvantages experienced by SMEs due to their lack of access to human resources, to external markets and to technology [67]. Similarly, the US and most OECD countries protect their SMEs by increasing the share of government contract to SMEs in the procurement process [29]. In a bid to increase the market share of SMEs, they are encourage to enter into the open public market through practicing procurement procedures [67], so developing more SMEs friendly approach to public procurement will allow SMEs to participate and benefit fully. Empirically, the Chinese Government through the Ministry of Finance and Ministry of Industry and Information Technology outlined a number of preferential procurement policies for SMEs to boost their development. Measures include, among others, requiring government departments, including the setting aside of $30 \%$ of annual budget for SMEs procurement and application of price differentials at the advantage of SME, while encouraging larger firms to subcontract to SMEs. The Korean The Korean Public Procurement Service Authority (PPS) also have their procurement procedures tilted in favor of the SMEs thereby pushing the SMEs to be able to compete with their larger counterparts for government contracts There are several benefit SMEs can derive from participating in public procurement which includes employment generation, able to deal with competition, 
and decreased influence of established networks of larger firms (that may exclude SMEs through collusive or corrupt bidding practices or otherwise). The fact is, SMEs needs qualified personnel backed by sound financial resources, therefore institutional support to SMEs in the training staffs on procurement issues and finance will go a long way to promote the growth of the SMEs sector.

H3: We therefore hypothesizes that, the provision of institutional support in the training of procurement personnel and financial backing will impact positively on SMEs growth.

\section{Methods and Data Analysis}

This study adopted a positive, quantitative and qualitative research approach [68]. According to [69] a quantitative approach ensured that the logical reasoning is applied to the research so that precision, objectivity and rigor replace hunches, experience and intuition as the means of investigation research problems'. Notwithstanding this benefit, [70] noted that a quantitative approach to the study of small business implied that some questions simply do not get asked or cannot be asked.

Evidence was collected in the form of taped interviews, and field notes using the daily diary approach. Also, focus groups representing a "diagonal slice" through the organization were interviewed to give broader and deeper data and to obtain triangulation [19] [71].

Wherefore, a psychometric analysis was used in finding the relationship between SMEs growth and TFE, TSM, AFM. The survey of the SMEs was done on a large scale, comprising 500 SMEs (owner/managers) in three regional capitals of Ghana. The questioners consist of two parts, with the first part concentrated on the biographic information of respondents and the second section consisting of Likert scale items demanding the extents of agreement and disagreement to items specified for the study regarding the impact of independent variables (Business Plan, Accounting \& Book Keeping and Procurement) on the dependent variable growth of SME (Net Access and Number of employees).

The use of both qualitative and quantitative approaches was to obtain in-depth information from the selected support institutions through interviews in addition to the primary data obtained through the use of the questionnaires.

The analysis of the quantitative data gathered was undertaken by the use of Statistical Package for the Social Sciences (SPSS), Microsoft excel and excel tool package. Obtained data was presented and analyzed using statistical techniques such as descriptive statistic (frequencies and simple percentages), Principal Component Analysis with Factor Analysis as an extraction method followed by a CFA to confirm the measurement items and a Structural Equation Model.

Validity and reliability test were computed to validate and confirm the strength of items on each constructs. Convergent and discriminant validity were considered for indications of validity problems whiles Composite and Cronbach's alpha values were examined for reliability issues.

Utilizing the stats tools package (excel), estimates were computed for convergent validity (with AVE and square root for AVEs). Composite reliability (CR) ratios were simultaneously computed for all factors and were compared with a minimum threshold of 0.70 . The next section describes in detail the outcome of the analysis.

\section{Presentation and Analysis of Research Data}

Given that this study explores the potential relationships between combinations of constructs, five modified scales from existing studies were used for data collection from purposively sampled views of 500 entrepreneurs located in three regions of Ghana. 437 cases constituting $87.4 \%$ were retrieved for analysis whiles respondents' bio-characteristics were not factored as prerequisites for selection. It is discernible that, 224 (51.3\%) males and 213 (48.7\%) females from which 104 (23.7\%) constituted SHS \& below education, 108 (24.7\%) with CERT/ DIP/HND, 113 (25.8\%) with first degree education and 112 (25.6\%) with above first degree education took part in the study. On the score of age, 100 (22.8\%) of them fell into the age range of 25 years \& below, 115 (26.3\%) fell into 26 to 35 years, 113 (25.8\%) fell into the age range of 36 to 45 years and respondents of ages 46 years and above constituted 109 representing 24.9\% (Table 1).

On the basis of [72] assertion about the need for screened data in research studies, the gathered data for this study was put through series of screening and cleaning. Dreadful issues of unengaged responses and missing data were outlined. The analysis adduced SD values ranging from 0.690 to 0.977 which obviously discern no dislikeable pattern of responses to the items for the study. Then again, normality assumptions were vehemently 
Table 1. Descriptive statistics of cases.

\begin{tabular}{|c|c|c|c|c|c|c|}
\hline & $\mathrm{N}$ & Mean & Std. Deviation & Variance & Skewness & Kurtosis \\
\hline & Statistic & Statistic & Statistic & Statistic & Statistic & Statistic \\
\hline Q1 Loan & 437 & 2.73 & 0.831 & 0.691 & 0.291 & -0.395 \\
\hline Q2 Loan & 437 & 2.86 & 0.894 & 0.799 & 0.104 & -0.804 \\
\hline Q3 Loan & 437 & 2.72 & 0.885 & 0.784 & 0.299 & -0.475 \\
\hline Q4 Loan & 437 & 3.09 & 0.913 & 0.834 & -0.286 & -0.681 \\
\hline Q5 Loan & 437 & 2.99 & 0.945 & 0.892 & -0.083 & -0.883 \\
\hline Q6 Subsidy & 437 & 2.88 & 0.897 & 0.804 & 0.064 & -0.627 \\
\hline Q7 Subsidy & 437 & 2.40 & 0.938 & 0.881 & 0.835 & 0.193 \\
\hline Q8 Subsidy & 437 & 2.36 & 0.977 & 0.955 & 0.706 & -0.090 \\
\hline Q9 Subsidy & 437 & 2.20 & 0.826 & 0.683 & 0.811 & 0.596 \\
\hline Q10 Subsidy & 437 & 2.25 & 0.913 & 0.834 & 0.707 & 0.020 \\
\hline Q11 Guarantee & 437 & 4.03 & 0.709 & 0.503 & -0.703 & 0.989 \\
\hline Q12 Guarantee & 437 & 3.97 & 0.702 & 0.493 & -0.696 & 1.299 \\
\hline Q13 Guarantee & 437 & 3.98 & 0.710 & 0.504 & -0.598 & 0.955 \\
\hline Q14 Guarantee & 437 & 3.98 & 0.691 & 0.477 & -0.597 & 1.135 \\
\hline Q15 Guarantee & 437 & 4.05 & 0.705 & 0.496 & -0.564 & 0.844 \\
\hline Q35SMEG & 437 & 3.88 & 0.725 & 0.526 & -0.891 & 1.892 \\
\hline Q36SMEG & 437 & 3.88 & 0.740 & 0.547 & -0.626 & 0.980 \\
\hline Q37SMEG & 437 & 3.75 & 0.762 & 0.581 & -0.727 & 0.989 \\
\hline Q38SMEG & 437 & 3.75 & 0.716 & 0.513 & -0.671 & 1.034 \\
\hline Q39SMEG & 437 & 3.47 & 0.909 & 0.827 & -0.256 & -0.365 \\
\hline Gender & 437 & 1.51 & 0.500 & 0.250 & -0.053 & -2.008 \\
\hline Age & 437 & 2.74 & 1.348 & 1.816 & 0.149 & -1.218 \\
\hline Education & 437 & 2.52 & 1.154 & 1.332 & -0.059 & -1.437 \\
\hline LOANS & 437 & 14.3979 & 3.68494 & 13.579 & -0.100 & -0.042 \\
\hline SUBSIDY & 437 & 12.0916 & 3.69287 & 13.637 & 0.625 & 0.442 \\
\hline GUARANTEE & 437 & 20.0105 & 3.17964 & 10.110 & -0.694 & 1.350 \\
\hline SME Growth & 437 & 18.7277 & 3.15134 & 9.931 & -0.737 & 1.606 \\
\hline
\end{tabular}

met as three rules from the central theorem [72] was applied in the study. The results obtained for both bio-data and the Likert scale items in Table 2 vigorously suggest no evidence of extreme problematic skewness and kurtosis issues, such that, the observed values for skewness ranged from -0.059 to 0.148 while the values for kurtosis ranged from -0.090 to 1.892 go to support.

Successively, the need to share light on concerns of discordant relationship between the data and the proposed model was equally imperative. In respect, matters of relationships, curves or equation as and quadratic, cubic, inverse, power, exponential, logistic, compound and logarithmic equations were concurrently examine in the research data and compared to the linear equation or relationship present in the data to evince whether the data gathered sufficiently beseem the proposed model. It is unambiguously discernible that, the research data strenuously befit the proposed model such that, the observed values for linear equation between all independent variables and the criterion variable is adequately significant, given the linear relationship between the SME Growth, Accounting \& Book Keeping, Procurement and Business Plan.

Thenceforward, from presence of linear relationships substantiated, matters of homogeneity and heterogeneity were examined. Variability in the values of the outcome variable was compared to the variability in the values predictor variables and eventualities of unequal variability across values of predictors and outcome variable 
Table 2. Model summary and parameter estimates of equations in the data set.

\begin{tabular}{cccccccccc}
\hline Equation & \multicolumn{3}{c}{ Account_BK } & & \multicolumn{3}{c}{ Procurement } & \multicolumn{3}{c}{ Business_Plan } \\
& R Square & F & Sig. & R Square & F & Sig. & R Square & F & Sig. \\
\hline Linear & 0.085 & 35.329 & 0 & 0.067 & 27.383 & 0 & 0.249 & 125.829 & 0 \\
Logarithmic & 0.073 & 29.919 & 0 & 0.066 & 26.667 & 0 & 0.23 & 113.194 & 0 \\
Inverse & 0.052 & 20.978 & 0 & 0.056 & 22.57 & 0 & 0.181 & 83.728 & 0 \\
Quadratic & 0.089 & 18.49 & 0 & 0.068 & 13.785 & 0 & 0.25 & 63.204 & 0 \\
Cubic & 0.09 & 12.386 & 0 & 0.068 & 9.185 & 0 & 0.263 & 44.959 & 0 \\
Compound & 0.08 & 32.931 & 0 & 0.065 & 26.303 & 0 & 0.235 & 116.996 & 0 \\
Power & 0.074 & 30.549 & 0 & 0.066 & 26.664 & 0 & 0.222 & 108.162 & 0 \\
Exponential & 0.08 & 32.931 & 0 & 0.065 & 26.303 & 0 & 0.235 & 116.996 & 0 \\
Logistic & 0.08 & 32.931 & 0 & 0.049 & 19.628 & 0 & 0.235 & 116.996 & 0 \\
\hline
\end{tabular}

The independent variable is Account_BK, Procurement and Business_Plan.

were noted as indication of heteroscedasticity. This was examined in a linear regression graph with outcome variable and the regression standardized residuals of predictor variables. Obviously, it is sighted on the graphical presentations that, there exist no extreme increase or decrease (widen or narrow) in the values of outcome variable as the values of predictors' increases or decreases (see Figures 1-3). In exposition, most of the dot plots do not depart/widens or decrease/narrow extremely from the regression fit line plotted for each predictor variable and the outcome variable which corroborates that, the research data is less or not heteroscedastic.

\section{EFA and CFA}

Currently many researchers have applied EFA to underline correlations among items or constructs in a data set [73]. In same tune, this study amply engages EFA technique to outline the extent of correlation among the specified items in this study and thenceforth extract items on their corresponding construct while obtaining unambiguous factor pattern. It is evidential from the output generated in Table 3 that, the research data profusely shows sufficient correlation for factor analysis with $\mathrm{X}^{2}$ of $5641.218387 \mathrm{DF}, 190$ significant at $p>0.01$. Then also, the Kaiser Mayor Oklin (KMO) measure of sampling adequacy is classified superb for obtaining a value of 0.903 .

Concurrently, all other assumptions regarding the observed values for communalities, MSAs, and the pattern of rotated component matrix were met in accordance with psychometric properties as shown in Table 4.

Resultantly, a measurement model was generated and validated in a covariance based method from the rotated factor matrix. The modification indices adduced suggested a clear opportunity to improve the measurement model. Respectively, the error terms e1, e3, e4 and e5 in the procurement construct, e14 and e15 in the accounting \& book keeping construct and e16, e17, e18, e19 and e20 in the SME Growth construct were simultaneously covaried to obtain a decent model shown in Figure 4).

The output from the analysis is tremendously telling on the relationships between observed measures (indicator) and their corresponding latent variables. It is clear from examining the goodness of fit indices that, the measurement model poses strong predictive ability $\mathrm{X}^{2}$ values, $p$-value and the Dfwhile Cmin, RMR, RMSEA, NFI and PCFI satisfactorily met their critical thresholds as shown in Table 5). Much further, same is true with the estimates for the paths of items to their latent variables $\beta=$ or $>0.50,0.60$ in most cases as shown in Figure 4) further confirming the level of fit of the measurement model.

From the measurement model, items and constructs are scrutinized in the research data to evince problematic issues of validity concerns. In the process, convergent validity was examined with computed AVEs and the square roots of AVEs were compared to inter-factor correlations. Concurrently, MSVs and ASVs were calculated and compared to justify the level of disparity among factors in the research model. Likewise, a composite reliability (CR) values were computed and compared to a threshold of 0.70 to indicate issues of problematic internal consistency of the survey items. As referenced in Table 6 the observed values for both MSV and ASV are 


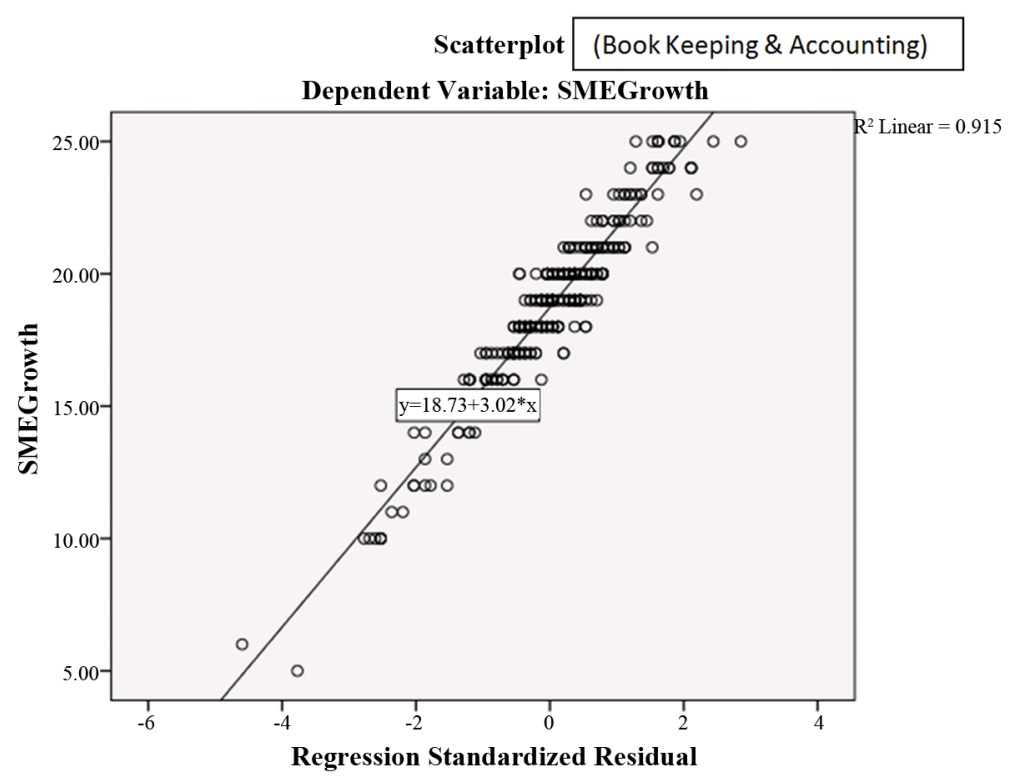

Figure 1. Scatterplots.

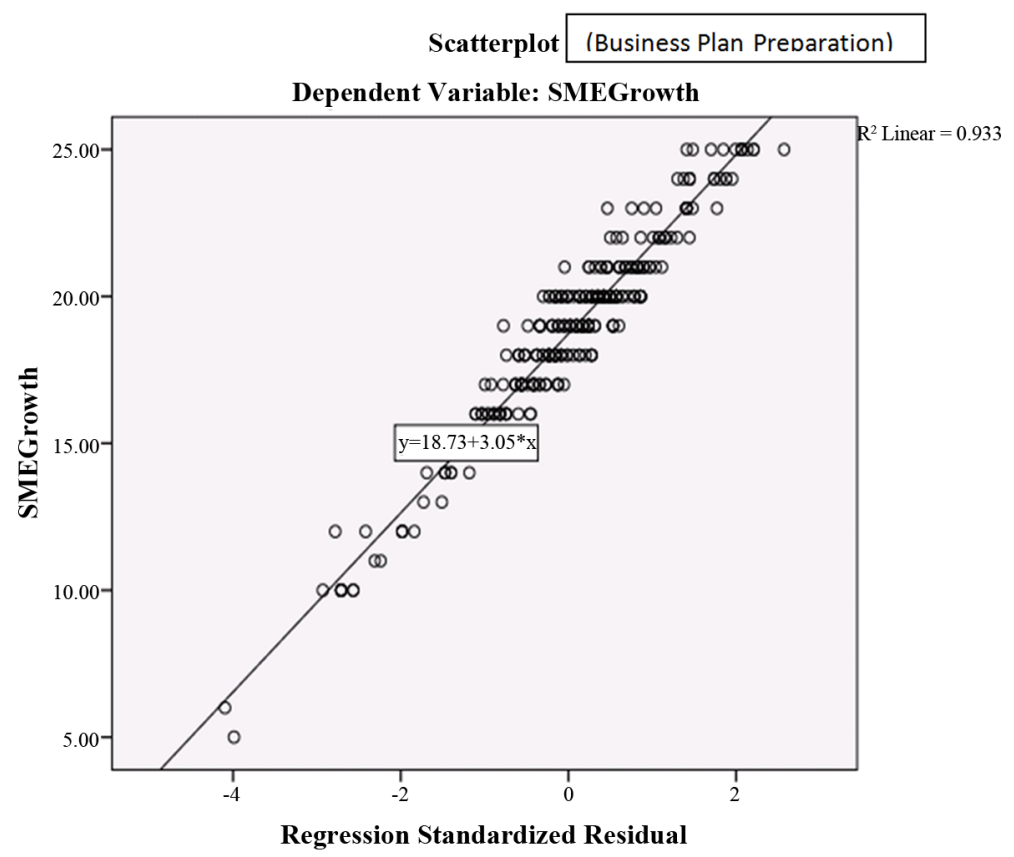

Figure 2. Scatterplots.

extremely less than the AVE values to explain the distinctiveness of the factors in the research model. In confirmation, the AVE values obtained were greater than 0.50 (all above 0.60 ) while the entire square roots of the AVEs on the diagonal matrix in Table 6 are far higher than the correlations among the factors. Similarly, the values obtained for CR were sufficiently above the minimum threshold of 0.70 , (observed values ranges from 0.873 to 0.958 ) with $p$-value $<0.001$ for the path loadings for all items and their latent constructs. Table 6 exhibits in detail.

Much further to appease multivariate assumptions in psychometric analysis is the Bias testing with Common Latent Factor (CLF) as recommended by [74] which account for the bias effects of the single method employed in this study and shows the effects from common ratters, consistency motif, mood state and common scale anchors on the research data. The results published in Table 6 displays a marginal effect from the CLF on the 


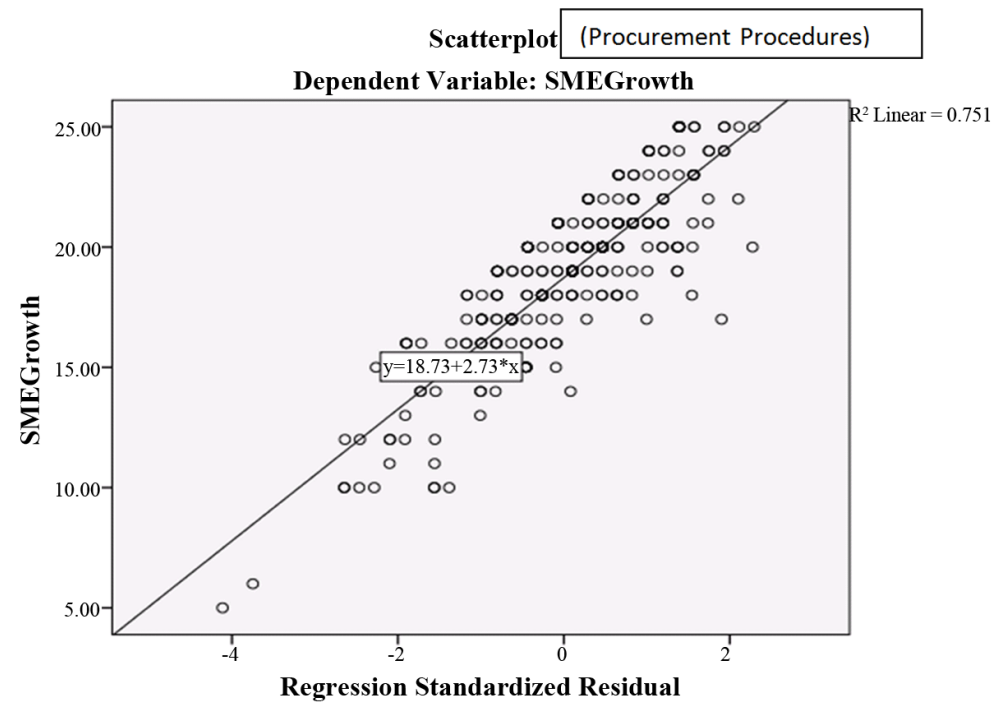

Figure 3. Scatterplots.

Table 3. Initial factor extraction.

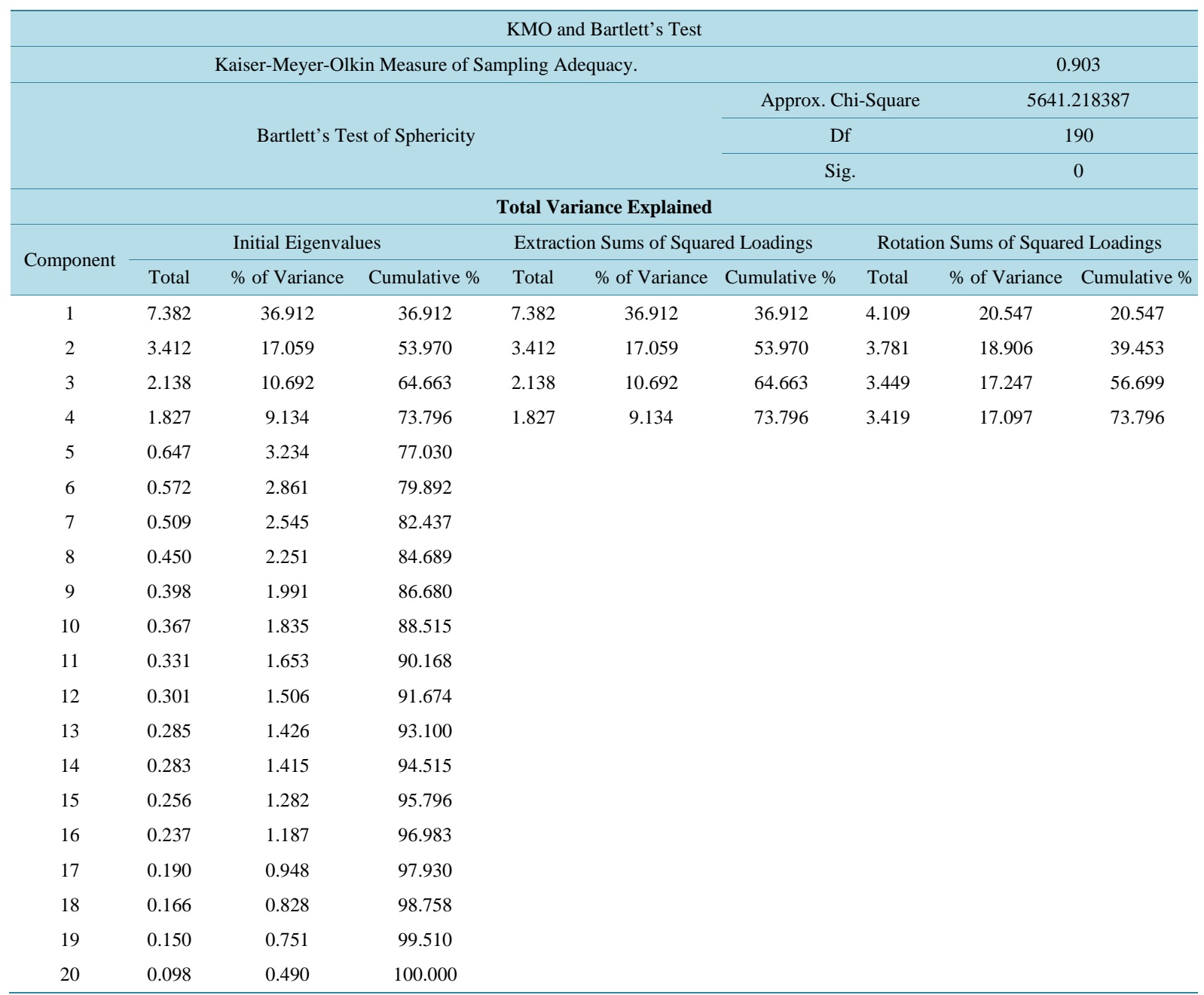

Extraction Method: Principal Component Analysis. 


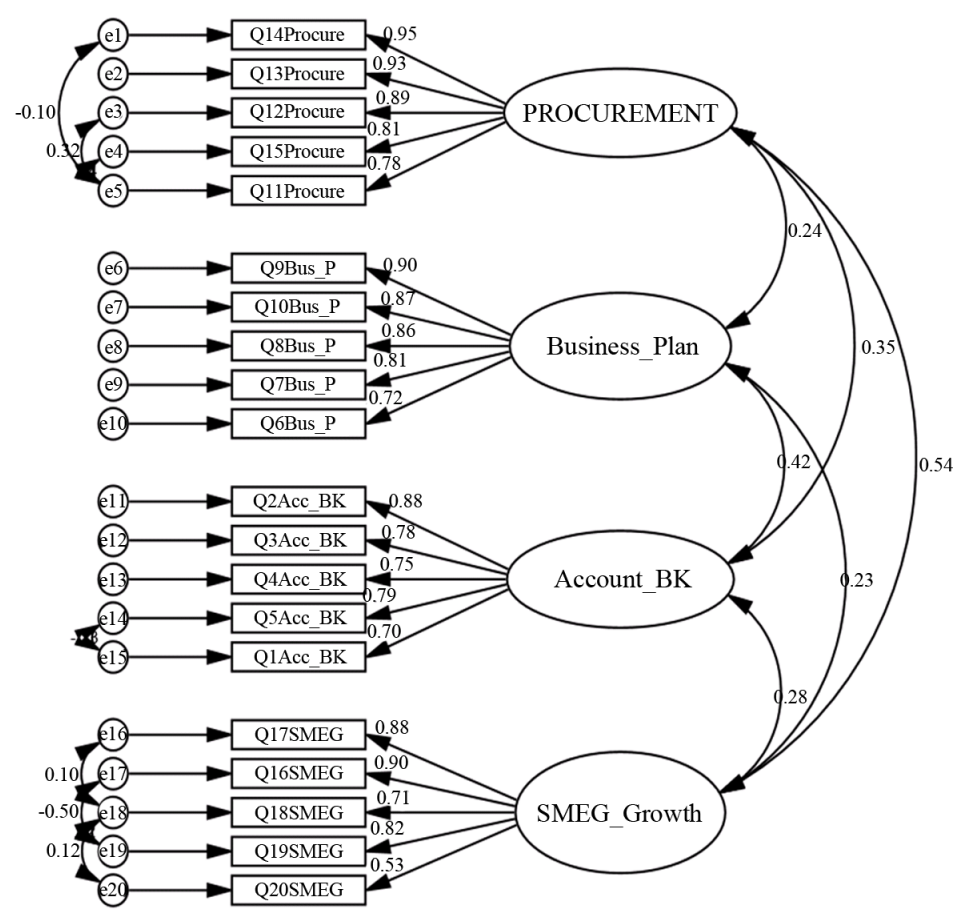

Figure 4. Measurement model.

Table 4. Rotated component matrix.

\begin{tabular}{|c|c|c|c|c|c|c|}
\hline \multirow{2}{*}{ INDICTORS } & \multicolumn{4}{|c|}{ Component } & \multirow[b]{2}{*}{ Communalities } & \multirow[b]{2}{*}{$\mathrm{MSA}^{\mathrm{a}}$} \\
\hline & 1 & 2 & 3 & 4 & & \\
\hline Q14Procure & 0.890 & & & & 0.872 & $0.870^{\mathrm{a}}$ \\
\hline Q13Procure & 0.876 & & & & 0.849 & $0.901^{\mathrm{a}}$ \\
\hline Q12Procure & 0.861 & & & & 0.851 & $0.924^{\mathrm{a}}$ \\
\hline Q15Procure & 0.849 & & & & 0.769 & $0.940^{\mathrm{a}}$ \\
\hline Q11Procure & 0.836 & & & & 0.754 & $0.917^{\mathrm{a}}$ \\
\hline Q9Bus_P & & 0.894 & & & 0.831 & $0.887^{\mathrm{a}}$ \\
\hline Q10Bus_P & & 0.876 & & & 0.798 & $0.899^{\mathrm{a}}$ \\
\hline Q8Bus_P & & 0.874 & & & 0.795 & $0.902^{\mathrm{a}}$ \\
\hline Q7Bus_P & & 0.818 & & & 0.729 & $0.925^{\mathrm{a}}$ \\
\hline Q6Bus_P & & 0.750 & & & 0.627 & $0.955^{\mathrm{a}}$ \\
\hline Q2Acc_BK & & & 0.865 & & 0.801 & $0.872^{\mathrm{a}}$ \\
\hline Q3Acc_BK & & & 0.814 & & 0.707 & $0.915^{\mathrm{a}}$ \\
\hline Q4Acc_BK & & & 0.791 & & 0.675 & $0.922^{\mathrm{a}}$ \\
\hline Q5Acc_BK & & & 0.783 & & 0.668 & $0.906^{\mathrm{a}}$ \\
\hline Q1Acc_BK & & & 0.702 & & 0.565 & $0.920^{\mathrm{a}}$ \\
\hline Q17SMEG & & & & 0.844 & 0.802 & $0.852^{\mathrm{a}}$ \\
\hline Q16SMEG & & & & 0.814 & 0.740 & $0.853^{\mathrm{a}}$ \\
\hline Q18SMEG & & & & 0.813 & 0.714 & $0.907^{\mathrm{a}}$ \\
\hline Q19SMEG & & & & 0.788 & 0.732 & $0.908^{\mathrm{a}}$ \\
\hline Q20SMEG & & & & 0.658 & 0.482 & $0.953^{\mathrm{a}}$ \\
\hline
\end{tabular}

Extraction Method: Principal Component Analysis. Rotation Method: Varimax with Kaiser Normalization. 
Table 5. Goodness of fit test (measurement model).

\begin{tabular}{ccc}
\hline \multicolumn{2}{c}{ Chi-square } & 181.799 \\
\hline \multicolumn{2}{c}{ Degrees of freedom } & 156 \\
\hline \multicolumn{2}{c}{ Probability level } & 0.077 \\
\hline \multicolumn{3}{c}{ Goodness of Fit Indices } \\
\hline CMIN/DF & Observed Values & Thresholds \\
CFI & 1.136 & 1 to 3 \\
RMR & 0.996 & $>0.95$ \\
GFI & 0.025 & $<0.09$ \\
AGFI & 0.958 & $>0.95$ \\
NFI & 0.942 & $>0.80$ \\
RMSEA & 0.97 & $>0.90$ \\
PCLOSE & 0.019 & $<0.05$ \\
\hline
\end{tabular}

Table 6. Validity and reliability.

\begin{tabular}{|c|c|c|c|c|c|c|c|c|c|}
\hline \multicolumn{10}{|c|}{ Validity and Reliability } \\
\hline & CR & AVE & MSV & ASV & Account_BK & Procurement & Business_Plan & SMEG_Growth & $\begin{array}{c}\text { Cronbach's } \\
\text { Alpha }\end{array}$ \\
\hline Account_BK & 0.887 & 0.613 & 0.173 & 0.125 & 0.783 & & & & 0.967 \\
\hline Procurement & 0.941 & 0.763 & 0.295 & 0.158 & 0.353 & 0.873 & & & 0.946 \\
\hline Business_Plan & 0.919 & 0.695 & 0.173 & 0.095 & 0.416 & 0.236 & 0.834 & & 0.824 \\
\hline SMEG_Growth & 0.883 & 0.609 & 0.295 & 0.142 & 0.278 & 0.543 & 0.234 & 0.780 & 0.935 \\
\hline
\end{tabular}

standardized regression weights after introducing the Common Latent Factor (CLF). It is authenticated in Figure 5 that, the deltas for most of the measurement items and the CLF are higher than 0.20 and 0.40 were the procurement construct is highly affect by the measurement method (see Table 7 for elaboration) however to be on the conservative was to maintain the CLF as composites are imputed from factor scores to adjust CMB.

After satisfying and meeting series of tests for multivariate analysis, and taking into concerns the hypotheses proposed for this study, a construct model was mounted with a covariance based method. Consequently, modification indices were cross checked to determine the level of fitness. Wherefore the model derived a good fit with all the observed ratios shown in the table below while meeting all criteria.

Given the acceptable fitness of the construct model, path estimates were generated for the effect of all predictor variables on the outcome variable while age, gender and education were controlled. Convincingly, the analysis amply displays the positive relationship between the predictor variables and the criterion variable as suggested by the estimated regression coefficients.

It is noticeable from Table 8 that, for every unit increase in managerial capacity building in terms of business plan, accounting \& book keeping and procurement, SME Growth will increase by 0.097, 0.129, and 0.129 approximately, as predicted by the estimated regression weights in the table above. Thus, approximately, $9.7 \%$ of the variability in SME Growth is explained by business plan, 12.9\% variability in SME Growth is explained by Accounting \& Book Keeping while $12.9 \%$ of the variability in SME Growth is attributable to procurement. Similarly, it is convincing that, the probability of obtaining high critical ratios of 1.883, 2.549 and 2.508 are less than $0.10,0.05$, and 0.01 as shown in the table above. From the analysis, the shared evidence goes to reinforce that, the variability in SMEs Grow is conclusively explainable by the independent variables specified in this model when all other predictor variables remain constant. The null hypotheses which suggest no effect from the predictor variables to the criterion variable (H0: $1, \mathrm{H} 0: 2, \mathrm{H} 0: 3, \beta=0$ ) is disputed for the Alternative hypotheses 


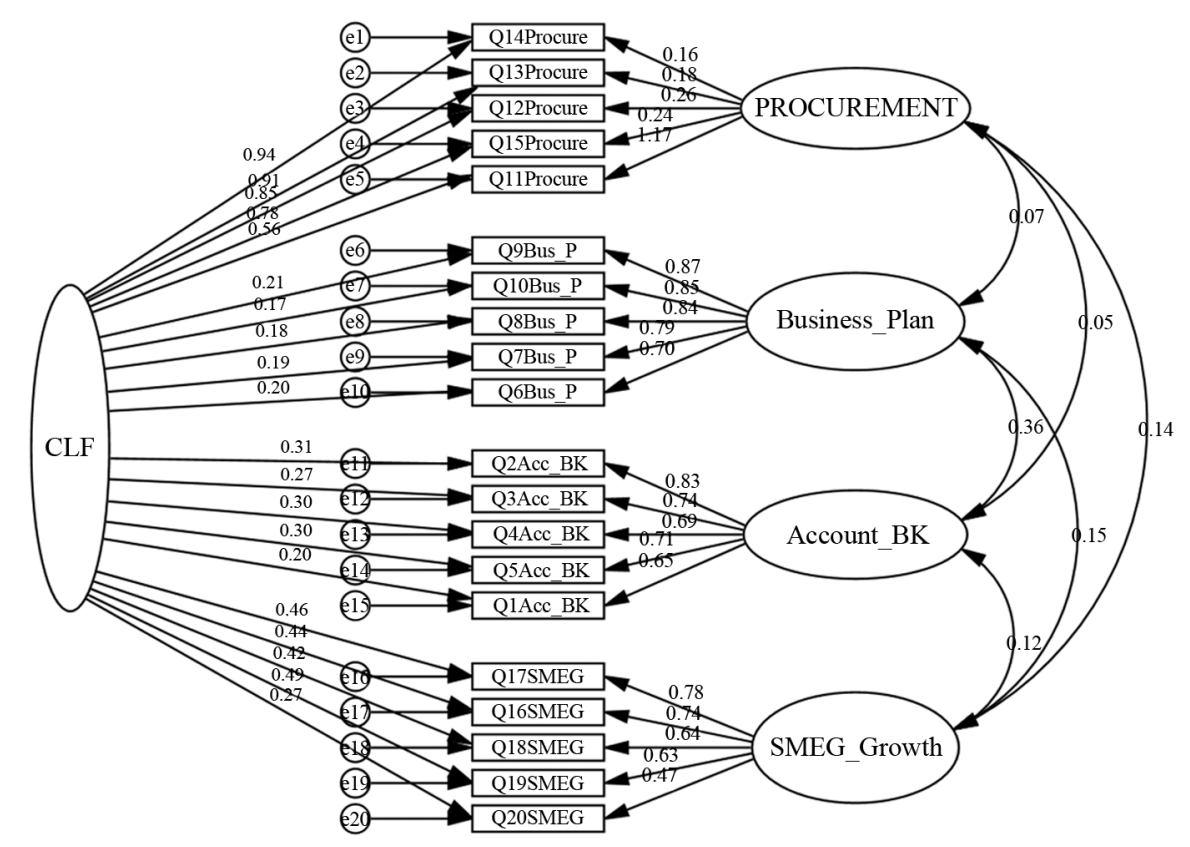

Figure 5. Construct model formulation and hypotheses test.

Table 7. Goodness of fit test for the construct model.

\begin{tabular}{ccc}
\hline \multicolumn{1}{c}{ Chi-square } & 178.571 \\
\hline & Degrees of freedom & 155 \\
\hline & Probability level & 0.184 \\
\hline & Goodness of Fit Indices & Thresholds \\
\hline CMIN/DF & Observed Values & 1 to 3 \\
CFI & 1.152 & $>0.95$ \\
RMR & 0.974 & $<0.09$ \\
GFI & 0.024 & $>0.95$ \\
AGFI & 0.985 & $>0.80$ \\
NFI & 0.94 & $>0.90$ \\
RMSEA & 0.969 & $<0.05$ \\
PCLOSE & 0.02 & $>0.05$ \\
\hline
\end{tabular}

Table 8. Paths estimates and hypotheses testing.

\begin{tabular}{ccccccccc} 
& Paths & & Estimate & S.E. & C.R. & P & Hypotheses & Remarks \\
\hline SME_Growth & $\leftarrow$ & Bus_Plan & 0.097 & 0.051 & 1.883 & 0.06 & H1 & ACEPT \\
SME_Growth & $\leftarrow$ & Accnt_Book & 0.129 & 0.044 & 2.549 & 0.011 & H2 & ACEPT \\
SME_Growth & $\leftarrow$ & Procurement & 0.129 & 0.067 & 2.508 & 0.012 & H3 & ACEPT \\
\hline
\end{tabular}

(H1: 1, H1: 2, H1: 3, $\beta \neq 0$ ) such that, these independent variables (Business Plan, Accounting \& Book Keeping and Procurement) are significant predictors of SME Growth as exhibited by the regression estimates. The forgoing discussion provides the bases for accepting the research hypotheses H1, H2, and H3 for which relevant recommendations are noted for SMEs in Ghana. 


\section{Discussion and Conclusion}

It is evidently clear from the study that, the presence of quality manpower has positive impact on the performance of SMEs, but most of the empirical literatures reviewed (refer to section 2) indicates that SMEs lack those quality manpower. Quality staff in the areas like the accountants, business planners, and procurement officers are lacking, this calls for the government and other support institutions to divert their support in other forms, (loans, subsidies) [75] [76], to assist in the training of management staffs of SMEs in the areas discussed. The entrepreneurs on the other hand, must open up their businesses to outside expertise, especially with most family businesses, where only members of the families are recruited irrespective of their expertise. Owner managers and management staffs should avail themselves, whenever there are workshops and other relevant training in management capacity building. Where applicable, entrepreneurs should fall on relevant students on vacations and attachment to beef up their managerial capacity, since student services normally come with no or little cost. The growing number of graduate unemployment in Ghana can also be exploited by entrepreneurs, but bearing in mind labor acts and regulations.

\section{Limitations of the Study}

In most cases, management was not separated from employees and ownership, making it difficult in identifying the targeted group. The businesses were scatted, compelling the researcher in targeting only those in the regional capital, because of time and financial constraints.

\section{References}

[1] Berger, A.N. and Udell, G.F. (1998) The Economics of Small Business Finance: The Roles of Private Equity and Debt Markets in the Financial Growth Cycle. Journal of Banking \& Finance, 22, 613-673. http://dx.doi.org/10.1016/S0378-4266(98)00038-7

[2] Galindo, A. and Fabio, S. (2003) Credit Constraints and Investment in Latin America. Inter-American Development Bank, Washington DC.

[3] Schiffer, M. and Weder, B. (2001) Firm Size and the Business Environment: Worldwide Survey Results. International Finance Corporation (Discussion Paper), FD43.

[4] Trulsson, P. (2002) Constraints of Growth-Oriented Enterprises in the Southern and Eastern African Region. Journal of Developmental Entrepreneurship, 7, 331-339.

[5] Batra, G.M. (2001) Direct Support to Private Firms: Evidence on Effectiveness. World Bank Policy Research Working Paper 3170.

[6] Batra, G. and Tan, H. (2003) SME Technical Efficiency and Its Correlates: Cross-National Evidence and Policy Implications. http://info.worldbank.org/etools/docs/library/74068/china/readings/oct30/tan30engl.pdf

[7] Beck, T., Asli, D.-K. and Levine, R. (2005) SMEs, Growth, and Poverty: Cross-Country Evidence. World Bank Mimeo. http://dx.doi.org/10.3386/w11224

[8] Ahmad, N.H. and Seet, P. (2009) Dissecting Behaviours Associated with Business Failure: A Qualitative Study of SME Owners in Malaysia and Australia. Asian Social Science, 5, 98-103. http://dx.doi.org/10.5539/ass.v5n9p98

[9] Portal, K.K. (2006) Keusahawanan: PUNB Perkenal Skim Usahawan Pemborong.

[10] Reiss, F. (2006) http://www.publishinggame.com/art_whysmallbusinessesfail.htm

[11] Chen, N.X., Fu, X.Z. and Bai, L. (2009) Zhongguo zhongxiao qiye fazhan baogao. Zhongguo jingji chubanshe, Beijing.

[12] Wangwe, S. and Rweyemamu, C. (2001) Human Resource and Institutional Development in Africa: An Overview. Economic and Social research Foundation (ESRF), Dar es Saleem

[13] Liedholm, C. and Mead, D. (1982) The Structure and Growth of Microenterprises in Southern and Eastern Africa: Evidence from Recent Surveys. Draft Paper, Department of Economics, Michigan State University, East Lansing, MI.

[14] Schmitz, H. (1982) Growth Constraints on Small Scale Manufacturing in Developing Countries: A Critical Review. World Development, 45, 1-66.

[15] Steel, W.F. and Webster, L.M. (1991) Small Enterprises in Ghana: Responses to Adjustment Industry. Series Paper No. 33, The World Bank Industry and Energy Department, Washington DC.

[16] Cowan, D.A. (1990) Developing a Classification Structure of Organisation Problems: Empirical Investigations. The Academy of Management Journal, 33, 366-390. http://dx.doi.org/10.2307/256329 
[17] Hall, O. (1995) Surviving and Prospering in the Small Firm Sector. Routledge, London.

[18] Lall, S. (2000) Strengthening SMEs for International Competitiveness. Workshop on "What Makes Your Firm Internationally Competitive?”, Egyptian Centre for Economic Studies, Cairo, 5-8 March 2000.

[19] Malhotra, N. and Birks, D. (2007) Marketing Research: An Applied Approach. Prentice Hall, Upper Saddle River.

[20] Parker, R., Riopelle, R. and Steel, W. (1995) Small Enterprises Adjusting to Liberalization in Five African Countries. World Bank Discussion Paper, No. 271, African Technical Department Series, The World Bank, Washington DC.

[21] Walsh, J.P. (1988) Selectivity and Selective Perception: An Investigation of Managers' Belief Structures and Information Processing. The Academy of Management Journal, 31, 873-896. http://dx.doi.org/10.2307/256343

[22] World Bank (1993) World Development Report. World Bank, Washington DC.

[23] Pfeffer, J. (1994) Competitive Advantage through People. Harvard Business School Press, Boston.

[24] Abduli, S. (2013) The Role of Recruitment and Training in SMEs’ Performance Growth in the Republic of Macedonia. International Journal of Academic Research in Business and Social Sciences, 2, 133-146.

[25] Armstrong, M. (2009) Armstrong's Handbook of Human Resource Management Practice. 11th Edition, Kogan Page, London.

[26] Lockett, J. (1992) Effective Performance Management. Kogan Page, London.

[27] Schendel, D. (1996) Evolutionary Perspectives on Strategy. Strategic Management Journal, 17, 1-4. http://dx.doi.org/10.1002/smj.4250171002

[28] Jackson, S.E., Schuler, R.S. and Rivero, J.C. (1989) Organizational Characteristics as Predictors of Personnel Practices. Personnel Psychology, 42, 727-786. http://dx.doi.org/10.1111/j.1744-6570.1989.tb00674.x

[29] OECD (2012) Financing SMEs and Entrepreneurs 2012: An OECD Scoreboard. OECD Publishing, Paris.

[30] Coskun, R. and Altunisk, R. (2001) Management’s Concerns about the Issues Faced by Turkish SMEs. International Journal of Entrepreneurial Behavior \& Research, 8, 272-291. http://dx.doi.org/10.1108/13552550210448366

[31] Huselid, M.A. (1995) The Impact of Human Resource Management Practices on Turnover, Productivity and Corporate Financial Performance. Academy of Management Journal, 38, 635-672.

[32] Macpherson, A. and Jayawarna, D. (2007) Training Approaches in Manufacturing SMEs: Measuring the Influence of Ownership, Structure and Markets. Education + Training, 49, 698-719. http://dx.doi.org/10.1108/00400910710834102

[33] Hughes, A. (1998) Growth Constraints on Small and Medium-Sized Firms. Working Paper No. 107, ESRC Centre for Business Research, University of Cambridge.

[34] Wren, C. and Storey, D.J. (2002) Evaluating the Effect of Soft Business Support upon Small Firm Performance. Oxford Economic Papers, 54, 334-365. http://dx.doi.org/10.1093/oep/54.2.334

[35] BIS (2013) Small and Medium-Sized Enterprise (SME) Journey towards Raising External Finance: A Report by BMG Research. Department for Business Innovation \& Skills.

[36] Carey, P. (2008) The Benefit Small and Medium-Sized Enterprises Derive from External Audit. Monash University, Melbourne.

[37] Cassar, G. and Holmes, S. (2003) Capital Structure and Financing of SMEs: Australian Evidence. Accounting \& Finance, 43, 123-147. http://dx.doi.org/10.1111/1467-629X.t01-1-00085

[38] Lee, G. and McGuiggan, R. (2008) Understanding Small- and Medium-Sized Firms’ Financial Skill Needs. Journal of International Finance and Economics, 8, 93-103.

[39] Shailer, G.E.P. (1999) The Relevance of Owner-Manager Signals and Risk Proxies to the Pricing of Bank Loans. Accounting and Business Research, 30, 57-72. http://dx.doi.org/10.1080/00014788.1999.9728924

[40] Shanmugam, B. (1998) Credit Management: The Risk Factor. University of New England, Armidale.

[41] Beck, T. and Robert, C. (2014) Banking in Africa. In: Berger, A., Molyneux, P. and Wilson, J., Eds., Oxford Handbook of Banking, 2nd Edition.

[42] Lambrecht, J. and Pimay, F. (2005) An Evaluation of Public Support Measures for Private External Consultancies to SMEs in the Valloon Region of Belgium. Entrepreneurship \& Regional Development, 17, 89-108. http://dx.doi.org/10.1080/0898562042000338598

[43] OECD (2014) Economic Outlook for Southeast Asia, China and India 2014: Beyond the Middle-Income Trap.

[44] IMF (2009) Ghana: Poverty Reduction Strategy Paper-2006 Annual Progress Report. Country Report No. 09/237.

[45] Yesseleva, M. (2013) Professional Advice and Its Possible Effect on Small and Medium-sized Enterprises’ Access to External Debt Finance in Australia. Global Business and Management Research, 5, 24.

[46] Mole, K.M., Hart, S.R. and Saal, D. (2008) Assessing the Effectiveness of Business Support Services in England: Evi- 
dence from a Theory Based Evaluation. CSME Working Papers.

[47] Bowen, M., Morara, M. and Mureithi, S. (2009) Management of Business Challenges among Small and Micro Enterprises in Nairobi-Kenya. KCA Journal of Business Management, 2.

[48] Longenecker, J.G., Moore, C.W., Petty, J.W. and Palich, L.E. (2006) Small Business Management: An Entrepreneurial Emphasis. Thomson South-Western, Mason.

[49] ISSER (2015) Workshop on Electricity Insecurity and Its Impact on the Economy of Ghana. University of Ghana, Legon, Accra.

[50] Chelimo, J.K. and Sopia, I.O. (2014) Effects of Bookkeeping on Growth of Small and Medium Business Enterprises in Kabarnet Town, Baringo County, Kenya. International Journal of Science and Research.

[51] Chimaleni, J., Muganda, M. and Musiega, D. (2015) Relationship between Sources of Business Financing and Financial Performance of Small and Medium Enterprises in Lurambi Sub-County. International Journal of Business and Management Invention, 4, 35-45.

[52] Chepkemoi, P. (2013) An Analysis of the Effect of Capital Structure of Small and Medium Enterprises on Their Financial Performance: A Case of Nakuru Town.

[53] Maseko, N., Manyani, O., Chiriseri, L., Tsekea, S., Mugogo, P.C., Chazuza, T. and Mutengezanwa, M. (2012) An Analysis of the Impact of Targeted Government Support on SMEs Growth and Development in Zimbabwe: A Survey of Mashonaland Central Province. Journal of Research in International Business Management, 2, 51-59.

[54] Afandi Ahmad, S. and Abd Latif, I. (2012) The Effectiveness of Public Advisory Services: What Are the Important Factors? International Journal of Business and Management, 7.

[55] Jayasekara, J.P.D.R. and Thilakarathna, A. (2013) Government Policy and Strategy for SME Development. The 4th IMF-Japan High-Level Tax Conference for Asian Countries, Tokyo, 2-4 April 2013.

[56] Delmar, F. and Shane, S. (2003) Does Business Planning Facilitate the Development of New Ventures? Strategic Management Journal, 24, 1165-1185. http://dx.doi.org/10.1002/smj.349

[57] Honig, B. and Karlsson, T. (2012) Institutional Forces and the Written Business Plan. Journal of Management, 30, 29-48. http://dx.doi.org/10.1016/j.jm.2002.11.002

[58] Carter, N., Gartner, W. and Reynolds, P. (1996) Exploring Start-Up Event Sequences. Journal of Business Venturing, 11, 151-166. http://dx.doi.org/10.1016/0883-9026(95)00129-8

[59] Team FME (2013) Ansof Matrix, Strategy Skills.

[60] Brinkmann, J., Grichnik, D. and Kapsa, D. (2010) Should Entrepreneurs Plan or Just Storm the Castle? A Meta-Analysis on Contextual Factors Impacting the Business Planning-Performance Relationship in Small Firms. Journal of Business Venturing, 25, 24-40. http://dx.doi.org/10.1016/j.jbusvent.2008.10.007

[61] Berry, M. (1998) Strategic Planning In Small High Tech Companies. Long Range Planning, 31, 455-466. http://dx.doi.org/10.1016/S0024-6301(98)80012-5

[62] Powell, T.C. (1992) Research Notes and Communications Strategic Planning as Competitive Advantage. Strategic Management Journal, 13, 551-558. http://dx.doi.org/10.1002/smj.4250130707

[63] Upton, N., Teal, E.J. and Felan, J.T. (2001) Strategic and Business Planning Practices of Fast Growth Family Firms. Journal of Small Business Management, 39, 60-72. http://dx.doi.org/10.1111/0447-2778.00006

[64] Gruber, M. (2007) Uncovering the Value of Planning in New Venture Creation: A Process and Contingency Perspective. Journal of Business Venturing, 22, 782-807. http://dx.doi.org/10.1016/j.jbusvent.2006.07.001

[65] Osiyevskyy, O., Hayes, L., Krueger, N. and Madill, C.M. (2013) Planning to Grow? Exploring the Effect of Business Planning on the Growth of Small and Medium Enterprises (SMEs). Entrepreneurial Practice Review, 2, 36-56.

[66] Baum, J.R. and Locke, E.A. (2004) The Relationship of Entrepreneurial Traits, Skill, and Motivation to Subsequent Venture Growth. Journal of Applied Psychology, 89, 587-598. http://dx.doi.org/10.1037/0021-9010.89.4.587

[67] ADB (2012) SME Development, Government Procurement and Inclusive Growth Publication Stock. ARM125221-3.

[68] Gill, J. and Johnson, P. (1991) Research Methods for Managers. Paul Chapman Publishing Ltd., London.

[69] Hussey, J. and Hussey, R. (1997) Business Research: A Practical Guide for Undergraduate and Postgraduate Students. Macmillan, London.

[70] Gartner, W.B. and Birley, S. (2002) Introduction to the Special Issue on Qualitative Methods in Entrepreneurship Research. Journal of Business Venturing, 17, 387-395. http://dx.doi.org/10.1016/S0883-9026(01)00077-5

[71] Saunders, M., Lewis, P. and Thorhill, A. (2007) Research Methods for Business Students. 4th Edition, Pearson Education Ltd.

[72] Berry, C.R. and Howell, W.G. (2007) Accountability and Local Elections: Rethinking and Retrospective Voting. The 
Journal of Politics, 69, 844-858. http://dx.doi.org/10.1111/j.1468-2508.2007.00579.x

[73] Russell, D. (2002) In Search of Underlying Dimensions: The Use (and Abuse) of Factor Analysis in Personality and Social Psychology Bulletin. Personality and Social Psychology Bulletin, 28, 1629-1646. http://dx.doi.org/10.1177/014616702237645

[74] Podsakoff, P.M., MacKenzie, S.B., Lee, J.-Y. and Podsakoff, N.P. (2003) Common Method Biases in Behavioral Research: A Critical Review of the Literature and Recommended Remedies. Journal of Applied Psychology, 88, 879-903. http://dx.doi.org/10.1037/0021-9010.88.5.879

[75] Beck, T. and Cull, R. (2014) Small- and Medium-Sized Enterprise Finance in Africa. Global Economy and Development Program, Vol. 16.

[76] Forkuoh, S.K. and Li, Y. (2015) SMEs Growth Influencers: An Exploratory Study on the Impact of Entrepreneur Character Traits on SMEs Growth in Ghana. British Journal of Economics, Management \& Trade, 9. 


\section{Appendix 1}

\section{QUESTIONNAIRES}

This research work is undertaking to have an insight on the impact of institutional support to SMEs managerial capacity building and growth in developing countries with much emphasis on Ghana.

All information you provide will be treated as confidential and anonymous, and also will be used for academic research only. Thank you.

\section{A TYPE OF MANAGERIAL CAPACITY BUILDING SUPPORT}

Please tick $(\sqrt{ })$ the most applicable ones to your business for the last three (3) years (2012-2015).
1. Strongly disagree
2. Disagree
3. Neither agree nor disagree
4. Agree 5. Strongly agree

\begin{tabular}{|c|c|c|c|c|c|c|}
\hline A & Training of Management staffs & 1 & 2 & 3 & 4 & 5 \\
\hline 1 & Employing well experienced staffs are too expensive for my business & & & & & \\
\hline 2 & I employ young people from the second cycle schools & & & & & \\
\hline 3 & Training staffs very expensive for my business & & & & & \\
\hline 4 & My marketing staffs are not up to the current techniques & & & & & \\
\hline 5 & My competitors have more competent marketing staffs. & & & & & \\
\hline 6 & There are no workshops for training of marketing staffs & & & & & \\
\hline 7 & The owner of the firm is in charge of accounting and book keeping & & & & & \\
\hline B & Business plan & 1 & 2 & 3 & 4 & 5 \\
\hline 8 & Workshops must be organized periodically at very cheaper rates & & & & & \\
\hline 9 & I have never prepared a business plan & & & & & \\
\hline 10 & My limited finances prevent me from attending business plan workshops & & & & & \\
\hline 11 & Business plan are for the larger companies & & & & & \\
\hline 12 & I am aware of the importance of in business plan & & & & & \\
\hline 13 & Business plan preparation is too technical & & & & & \\
\hline $\mathbf{C}$ & Procurement & 1 & 2 & 3 & 4 & 5 \\
\hline 14 & I am not aware of any procurement laws & & & & & \\
\hline 15 & Workshops on procurements are regularly organize & & & & & \\
\hline 16 & Procurement processes are too cumbersome & & & & & \\
\hline 17 & Micro firms are not involve in government contract & & & & & \\
\hline 18 & My staffs need training in procurement procedures & & & & & \\
\hline $\mathbf{D}$ & GROWTH INDICATORS OF SMEs & 1 & 2 & 3 & 4 & 5 \\
\hline 19 & The business is labor intensive & & & & & \\
\hline 20 & The labor force has increased significantly over the years & & & & & \\
\hline 21 & I employ more relevant experienced people & & & & & \\
\hline 22 & Academic qualification of my employees counts & & & & & \\
\hline 23 & Full time employees are more than part time and contract employees & & & & & \\
\hline 24 & The number of hours worked by employees has increased significantly & & & & & \\
\hline 25 & The output per employee has gone up significantly & & & & & \\
\hline 26 & More capital goes are used in place of labor & & & & & \\
\hline 27 & My wage bill has gone up & & & & & \\
\hline 28 & Employees welfare benefits has gone up & & & & & \\
\hline 29 & There has been a significant increase in total sales & & & & & \\
\hline 30 & The customer base of the business has increased & & & & & \\
\hline 31 & Existing customers has increased their purchases & & & & & \\
\hline 32 & New customers has been recorded & & & & & \\
\hline 33 & Profit has increased due to increase in sales revenue & & & & & \\
\hline 34 & More branches have been opened & & & & & \\
\hline 35 & I access overseas market & & & & & \\
\hline 36 & Dividends to shareholders has increased significantly & & & & & \\
\hline
\end{tabular}




\section{E. General Questions}

Please provide one answer to each of the following general questions on your business.
37. Gender? 1: Male
2: Female
38. Age? 1: 20 - 30
2: 31 - 40
3: $41-50$
4: 51 - 60
5: 61 and above

39. What is the highest educational level of the owner or general manager of the business?
1: Less than high school diploma
2: High school diploma
3: A bachelor's degree
4: A master's degree or above
5: Others

40. Which of the following best describes your position in this business? Are you...

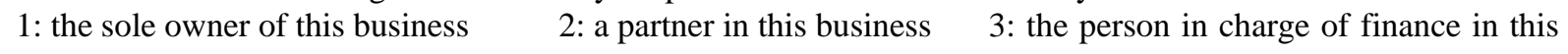
business 4: general manager 5: occupying another position in this business

41. Type of the business Organization?

1: a sole proprietorship 2: a partnership $\quad 3:$ a franchise $\quad 4$ : a joint venture $\quad$ 5: others

42. How long has your business been in existence?

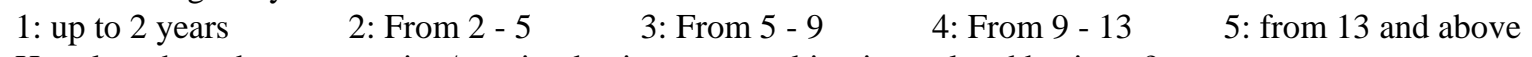

How long have been managing/running business or working in a related business?

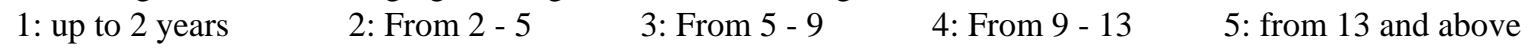

43. What was your enterprise average total number of employees as at 2013 and 2015 ?

In 2013

1: 1 - 5

In 2015

2: $6-9$

3: 10 - 29

4: $30-250$

5: Other

1: 1 - 5

2: 6 - 10

3: $11-15$

4: 16 - 29

5: 30 and above

44. What was your enterprise's average total turnover for 2013 and 2015 in New Ghana Cedis $(\mathrm{GhC})$

1: up to $\$ 10,000$

2: above $\$ 10,000$

44. Location of the business?

45. In 2015, did your business... (Mark all that apply.)

: Import goods or services from outside your home country?

: Outsource (contract out) any business activities from home country to another country?

: Sell goods to a business in your home country that used them as an intermediate input in the production of another good that was then exported?

: Engage in foreign direct investments?

: Engage in other international business activities? 